\title{
Een theologische faculteit als huis van vele woningen: Over de institutionalisering van de theologie in de pluralistische, seculiere samenleving
}

H Vroom $^{1}$

(Vrije Universiteit, Amsterdam)

\section{ABSTRACT}

A theological faculty as a house with many rooms: On the institutionalisation of theology in a pluralistic, secular society.

Religious pluralism is changing the Western world. The transmission of Christian faith is less a matter of course than it has been. People are free to form their own opinions and 'choose' their way of life. Because pluralism affects the basic values of society that have to be supported by world view traditions, religious pluralism is one of the main political problems of the 'secular' state as well. Faculties of Theology can be organised better as apartments buildings for religions with common rooms, exchange and debates, instead of gradually becoming departments of descriptive religious studies. A public inter-religious dialogue on values and political issues will be supported by such an institution, and prevent accountability for views of life to disappear from the public arena into privacy and hidden places. Students can be educated in plural theological faculties of universities that reflect societal realities, in an atmosphere of respect, integrity, dialogue and accountability.

The first section of this contribution describes the changing situation in the European (EU) culture; the second the consequences of pluralism for churches; the third the crisis of traditional theology; and the fourth points out the perspective of a plural but confessional institutionalisation of theology/ies.

\section{INLEIDING}

De 'Westerse' christelijke theologie staat voor grote veranderingen. De globalisering en de pluralisering van de cultuur gaat niet aan haar voorbij. In deze bijdrage zal ik de ontwikkelingen beschrijven, de gevolgen voor kerk en theologie duiden en uiteenzetten waarom de theologie in de plurale cultuur om een andere organisatie van de

1 Navorsingsgenoot, Prof C J Wethmar, Departement Dogmatiek en Christelike Etiek, Universiteit van Pretoria. 
geloofsdoordenking vraagt $^{2}$. Op de achtergrond staan eerdere publicaties van Conrad Wethmar en schrijver dezes 3 . We schreven niet alleen beiden een dissertatie op het gebied van de hermeneutiek, maar werkten ook samen in twee projecten over de institutionalisering van de theologie; in 1996 in een project van de Teologische Fakulteit in Pretoria over diverse modellen om oecumenische samenwerking in de theologie te organiseren, en in 2000 in een project over 'Theology between the Academy, Church, and Society'. Deze bijdrage ligt in het verlengde van deze 'navorsingsprojecten' en handelt over het thema Theologie en Publiek domein - Universiteit, dat Conrad Wethmar gedurende de ontwikkelingen in Zuid-Afrika steeds heeft bezig gehouden, zowel in de theorie als in de praktijk.

Na de Inleiding schets ik in de tweede paragraaf de veranderingen in de cultuur die het bestaande paradigma van de

2 Er bestaat veel literatuur over de culturele en maatschappelijke ontwikkelingen in de West-Europese cultuur, maar minder over die in de theologie. Deze bijdrage steunt in sterke mate op persoonlijke ervaring. Daarom zal ik hier enkele verbanden noemen waarin ik bij deze zaken betrokken ben of ben geweest, zodat de lezer zich enigszins een oordeel kan vormen over de herkomst van de meningen in deze bijdrage: de onderzoekgroep Ontmoeting van tradities; het Centrum voor Islamitische Theologie aan de Vrije Universiteit te Amsterdam, VISOR (VU-Institute for the Study of Religion, Culture, and Society); het bestuur van de Nederlandse OnderzoekSchool voor Theologie en Religiewetenschappen NOSTER; de Interfaith Committee van de Nederlandse Raad van Kerken; de European Sociey for Intercultural Theology and Interreligious Studies (ESITIS); en voordien de European Area Committee of the World Alliance of Reformed Churches; de Universitaire Toetsingscommissie van de VU (advisory committee on research); het Bestuur van het Wetenschappelijk Instituut van het CDA - verbanden waarin steeds vragen over pluralisering van de samenleving, de plaats van de levensbeschouwing op het publieke domein en van de theologie aan de orde zijn.

3 In 1996 ging het over het dilemma tussen een faculteit met een godsdienstwetenschappelijke basis en confessioneel-bepaalde theologische vervolgopleidingen (duplex ordo) of een oecumenische theologische opleiding met eigen accenten voor denominaties (simplex ordo) - daarna gepubliceerd in Skrif en Kerk (1997-8). In 2000 ging het zowel om de theologie in eigenlijke zin en de vergodsdienstwetenschappelijking als over simplex/duplex ordo. Conrad Wethmar beschreef toen de ontwikkelingen in de Teologische Fakulteit van Pretoria en gaf een uitvoerige nabeschouwing over de gehele bundel (2003). 
'neutrale, liberale staat' doorbreken en de vergaande consequenties van de levensbeschouwelijke pluralisering van de samenleving: van Verlichtingsparadigma tot dialoog. Mensen maken individuele keuzen op de levensbeschouwelijke 'markt'. De veranderingen in de cultuur brengen de klassieke christelijke theologie in een crisis. In de derde paragraaf schets ik deze crisis. Tot slot geef ik argumenten voor de ontwikkeling van een Faculteit voor de Studie van Religies en Levensbeschouwingen waarbinnen ieder de eigen traditie bestudeert en zoekt naar verantwoord geloof. Binnen deze Faculteit heeft de dialoog een vanzelfsprekende plaats. Ik ga niet in op de ingrijpende verschillen tussen de wereldreligies en hun overlappingen (zie Gort et al. 2006) en noem kortheidshalve elke bezinning op religie en seculiere levensbeschouwing theologie.

In deze Inleiding schets ik de ingrijpende veranderingen die we in de West-Europese cultuur meemaken. De meeste grote steden in West-Europa kennen een sterk gemengde bevolking. Temidden van de 'oorspronkelijke bewoners' leven er veel mensen die uit de vroegere koloniën afkomstig zijn. In Nederland bestaan de 'oorspronkelijke bewoners' in de steden traditioneel ook voor een hoog percentage uit nageslacht van vluchtelingen - protestanten uit Frankrijk en het huidige België en joden uit Spanje en Polen - en mensen die om redenen van armoede vooral uit Duitsland naar de Lage Landen zijn getrokken. Vanaf de jaren zestig van de twintigste eeuw zijn er grote groepen 'gastarbeiders' binnen gekomen, die na verloop van tijd hun gezin mochten laten overkomen. Ook uit landen met gewelddadige conflicten zijn er vluchtelingen gekomen - vaak hoger opgeleid. Deze groep verschilt van de mensen die als gastarbeiders zijn gekomen. Gastarbeiders bezoeken hun familie in het land van herkomst met grote regelmaat; men voelt zich voor elkaar verantwoordelijk; het percentage huwelijkspartners uit de streek van herkomst daalt maar ligt deze jaren op ongeveer de helft van het aantal huwelijken - wat leidt tot nieuwe instroom van mensen zonder kennis van de taal en de cultuur. Veel vluchtelingen hebben hun schepen achter zich verbrand; voormalige gastarbeiders niet. Bovendien zijn veel van de gastarbeiders moslim. Alleen al door de gebedstijden en de ramadan en afwijkingen van de (post-) christelijke inrichting van de cultuur, manifesteert de islam zich in de publieke ruimte (Scheffer 2007:37).

In de Europese Unie leven meer dan tien miljoen mensen met een islamitische achtergrond. Frankrijk, België en Nederland hebben 
het hoogste percentage moslims (respectievelijk ongeveer 8\%, 6\% en 6\%). De islamitische bevolking leeft als alle nieuwkomers hoofdzakelijk in de steden. In sommige wijken van grote steden als Amsterdam en Utrecht en kleinere als Roermond is bijna de helft van de bevolking moslim. Daarnaast is er een bijna even groot percentage van de 'nieuwe' bevolking christen, zodat er in Parijs en Lyon, in Brussel en Amsterdam veel niet-westerse christenen zijn: uit voormalige koloniën afkomstig of als vluchteling naar Europa gekomen. De scholen in deze wijken worden 'zwarte scholen' genoemd. Een moeilijkheid van zulke wijken met 'nieuwe' Nederlanders is dat de beheersing van het Nederlands sterk tekort schiet, waardoor een groot deel van de jongeren in opleidingen en beroepen terechtkomt waarin men weinig taalvaardigheid nodig heeft, en veel werkeloosheid. Er bestaat reëel gevaar voor segregatie. Met name vrouwen kunnen in de grote steden leven zonder de Nederlandse taal te spreken. Omdat delen van de nieuwe bevolking niet sterk mengen met de oude bevolking, blijven cultuurverschillen een grote rol spelen.

Na de aanslagen in New York is de vrees voor 'de Islam’ sterk toegenomen. De aanslagen die Al-Kaida en verwante groepen wereldwijd plegen houden die angst levend. Dat sommige van de aanslagplegers van 9/11 in Hamburg hadden gestudeerd en de gewelddadige jongeren die Nederland en Engeland werden gearresteerd uit eigen land afkomstig waren, maakte de spanningen rond radicale moslims en achtergebleven groepen tot een intern probleem van West-Europese landen. Nuances worden daarbij over het hoofd gezien; men spreekt meestal massief over 'de Islam'. Er is een tendens tot wat ik 'etnisering' van 'de Islam' zou willen noemen, ook al heeft men juist niet één taal, één geschiedenis en eenzelfde culturele achtergrond. Toch scheren de krasse islamcritici hen over één kam. De verschillende islamitische richtingen kiezen hun eigen ontwikkeling en ook de mate en de manier waarop zij integreren loopt wijd uiteen.

Alle landen van de EU worstelen met de plaats van de nieuwe religie, de Islam. Tegelijk verheugen ook andere wereldreligies zich in een zekere mate van populariteit. Hindoe-gemeenschappen zijn uit India en het Caraïbische gebied afkomstig. Een aanzienlijk percentage jongere goedopgeleide mensen wordt geïnspireerd door boeddhistische stromingen. Religie is 'terug van weggeweest'. De opleving van religiositeit wereldwijd maakt een eind aan de 
populaire secularisatiethese - zoals bijvoorbeeld Peter Berger ruiterlijk toegeeft; hij legt er ook nadruk op dat religie niet in de oude vormen terugkeert maar in nieuwe (Berger 1999). De sterke secularisatie in een groot aantal Europese landen is, wereldwijd gezien, een 'exceptional case’ (Davie 2002:1-26, 138-50).

Door de globalisering en in Europa de eenwording in de Europese Unie hebben de Europese regeringen veel van hun macht verloren. De veranderingen treffen ook het sociale stelsel dat in de landen aan de rivier de Rijn in een hoge mate van bestaanszekerheid voorzag: het 'Rijnlandse economische model' met zijn nadruk op solidariteit. Door de wereldwijde competitie is het recht op sociale bijstand sterk ingekrompen - voor een deel ook terecht want waarom zou iemand van vijftig jaar oud die zijn baan verliest in een ruim aantal gevallen tot zijn pensioen zonder te werken grotendeels worden doorbetaald? Door deze kortingen op de solidariteit neemt de 'sociale geborgenheid' af en bijgevolg de onzekerheid toe. De kleinere gezinnen en de toegenomen modernisering en complexiteit van de samenleving maakt dat jonge mensen in sterke mate hun eigen weg in het leven moeten vinden; men spreekt van 'risicosamenleving'. Deze ontwikkeling heeft stellig bijgedragen aan een toenemende belangstelling voor 'religie en spiritualiteit'. De vraag naar zin en onzin van het leven laat zich moeilijker onderdrukken.

Terwijl de klassieke kerkelijke richtingen veel van hun kracht hebben verloren, staat religie vanaf het einde van de twintigste eeuw weer meer in de belangstelling. Men waarschuwt er terecht voor om dit niet als een terugkeer van de oude situatie te beschouwen, want de structuren van religieuze gemeenschappen verschillen. Aan de ene kant van het spectrum zijn er de talloze bricoleurs, die uit de veelheid van het religieuze aanbod hun eigen geloof en leefwijze samenstellen, aan de andere kant de vormen die men 'strong religion' heeft genoemd (Almond 2003).

Deze ontwikkelingen raken de klassieke theologie in haar kern. Traditioneel is de theologie met kerken verbonden, maar de kerken verliezen veel van hun gezag - zowel aan de kant van de bricoleurs als bij 'strong religion'. Islamitische en christelijke jongeren gaan bij websites te rade. Traditioneel opgeleide predikanten met grondige kennis van Hebreeuws en de dogmatische klassieken komen vaak niet toe aan de geloofsvragen waarmee hun gemeenteleden 
worstelen. De traditionele christelijke theologische studie is - of men het prettig vindt of niet - zowel vanuit de kerk als vanuit de samenleving gezien aan een grondige heroriëntatie toe. De theologie heeft een taak: hoe anders scheiden we het religieuze kaf van het spirituele koren?; wie anders brengt studenten met de diepere lagen van tradities in aanraking?

\section{VAN VERLICHTINGSPARADIGMA TOT DIALOOG}

Na de Tweede Wereldoorlog brak een periode aan waarin de koloniën van West-Europese landen zelfstandige staten werden. Het koloniale beleid had naast handelsbelangen als een van de leidende gedachten dat de Westerse 'beschaving' - ik zie ervan af om in deze bijdrage hieronder vele begrippen tussen aanhalingstekens te schrijven - een hoger stadium van de ontwikkeling van de mensheid vertegenwoordigde. Deze gedachte had christelijke wortels maar was ook sterk door de Verlichting bepaald. Christenen wilden idealen van gelijkheid, barmhartigheid en solidariteit verbreiden; men denke aan diaconaat, zending en katholieke congregaties. In de tijd van de Verlichting werden deze idealen met vooruitgangsdenken verbonden zodat de notie 'heidense volkeren' of, milder, 'volkeren aan wie men het Evangelie mocht brengen' verbonden werd met een historische beoordeling als minder en meer ontwikkeld - en met Idealistische en Romantische, 'organologische' ideeën over de ontwikkeling van volkeren met elk een eigen 'ziel' en plaats in het grote historische proces. Het verband met de gedachte aan apartheid is helder. In de tijd van de 'Pacific War' vinden we de gedachte van een superieure cultuur overigens ook in Japan met consequenties voor de rol van Japan in Oost-Azië. Deze ordening van culturen heeft diepe sporen getrokken in de negentiende en vooral in de twintigste eeuw. De wonden die door de praktische gevolgen van de beoordeling van volkeren en culturen als 'hoger' en lager' zijn ontstaan, zijn nog lang niet geheeld. Maar, zoals zo vaak, de reactie op de onrechtvaardige nadruk op cultuurverschillen loopt gevaar in een tegengestelde fout te vervallen, zoals cultuurrelativisme of de verwaarlozing van culturele en religieuze verschillen. Omdat dit punt centraal is voor wat volgt, ga ik er iets dieper op in.

Het tegendeel van een ordening van culturen als lager en hoger - zeg: cultuurprioritering - is cultuurrelativisme, dat alle culturen gelijkwaardig acht en ervan uitgaat dat er geen boven-culturele, universele maatstaven bestaan waarmee men de waarde van culturen 
kan beoordelen. De schema's van de verschillende culturen zijn incompatibel: het is onmogelijk om ze geheel te begrijpen. Omdat een cultuur een geheel vormt, kan men de waarde van onderdelen van diverse culturen - bijvoorbeeld de man-vrouw-verhouding - ook niet tegen elkaar afwegen. Cultuurprioritering en cultuurrelativisme staan weliswaar tegenover elkaar inzake de waarde van culturen, maar zij delen één grote vooronderstelling: dat culturen 'gehelen' vormen. Het zijn beide massieve, holistische visies op 'een cultuur' - de één vanuit een westerse vooruitgangsidee, de andere vanuit de gelijkwaardigheid van verschillende culturen. Het zal duidelijk zijn dat deze visies op cultuur hun parallellen hebben wat betreft religie en de verhouding tussen religies. Ook hier kan men vanuit een reïficatie van religie - 'de islam', 'het hindoeïsme' - tot een gradatie qua niveau van beschaving en waarheid komen of tot een nevenschikking en relativering van waarheidsaanspraken - de 'pluralismethese'. Wilfred Smith (1964) wees in 1962 al op de onhoudbaarheid van reïficatie van religieuze tradities.

Wat de cultuur betreft wordt deze holistische visie tegenwoordig door cultureel-antropologen meestal afgewezen als essentialistisch: alsof culturen een essentie, een wezen, zouden hebben dat hun identiteit uitmaakt en onveranderlijk is. Culturen zijn dynamische, contextuele en complexe verschijnselen die in zichzelf pluraal zijn en zich verder ontwikkelingen in wisselwerking met andere culturele tradities. Het overeenkomstige kan men van religies zeggen. Ook zij zijn historisch gegroeide fenomenen die men niet lichtvaardig op een noemer mag brengen. Het probleem hierbij is dat er ontegenzeggelijk verschillen tussen culturele tradities bestaan die mensen om strategische redenen kunnen benadrukken of verdoezelen ${ }^{4}$. Ook de ontkenning van cultuurverschil kan uit strategische motieven voortkomen en dienstbaar zijn aan de identiteitsconstructie en emancipatie van een groep mensen. Cultuurverschillen spelen onmiskenbaar een grote rol in intermenselijke verhoudingen en kunnen niet alleen problemen opleveren als men ze overdrijft of negeert maar ook als men over het hoofd ziet dat culturele en religieuze identiteitsconstructies kunnen worden gebruikt op grond van persoonlijke en gemeenschappelijke belangen. Cultuur en levensbeschouwing zijn met elkaar verweven,

4 Men denke aan studies over de 'invention of tradition' en identiteitsconstructie. 
want levensbeschouwingen omvatten een visie op waarden, en culturen zijn op waarden gebouwd. Men moet dus onderscheiden tussen religie en cultuur maar men kan ze niet van elkaar losmaken. Om een voorbeeld te geven, dat veel moslimse mannen vrouwen geen hand geven, is een cultureel gegeven met een religieus-ethische motivatie, de zedigheid. De hoogachting voor de profeet Mohammed is religieus, maar werkt door in de wetgeving van islamitische staten en heel de cultuur (Okumus 2008). Omdat religie en cultuur zo nauw verweven zijn, kan men vaak beter van religio-culturele tradities spreken.

De specifieke moeilijkheid van politiek beleid inzake cultuur, religie en integratie komt voort uit het feit dat men met vier inzichten moet rekenen die zich niet gemakkelijk laten verbinden: 1) culturele en religieuze identiteiten zijn historisch gegroeide, groepsgebonden constructies; 2) tussen religieuze en culturele groeperingen bestaan aanmerkelijke verschillen in gewoonten, waarden en opvattingen; 3) culturele en religieuze tradities ontwikkelen zich in wisselwerking met elkaar en de verdere context; 4) een cultuur behoeft een aantal gemeenschappelijke waarden, normen en gewoonten, en dus ook voldoende gemeenschappelijke inzichten in het leven.

De erkenning van de eerste drie punten samen levert een probleem op voor de realisering van het vierde. Hoe realiseren wij gemeenschappelijkheid op de werkvloer, op de school en in de straat en hoe bouwen we aan een sociaal stelsel dat mensen bestaanszekerheid biedt en sociale samenhang schept? Wie de eerste drie inzichten beaamt, kan gemeenschappelijkheid niet meer deductief uit een idee van universele menselijkheid afleiden, maar zal haar inductief moeten 'vinden' in het proces van de wisselwerking tussen mensen uit verschillende tradities.

Deze constatering heeft twee belangrijke consequenties. In de eerste plaats vervalt hiermee de mogelijkheid om mondiale waarden en normen af te leiden uit één van de religio-culturele tradities. Dit heeft gevolgen voor de status van het eerste artikel de van de Universele Verklaring van de Rechten van de Mens (1948): 'Alle mensen worden vrij en gelijk in waardigheid en rechten geboren. $\mathrm{Zij}$ zijn begiftigd met verstand en geweten, en behoren zich jegens elkander in een geest van broederschap te gedragen.' Deze zinsnede is niet de uitkomst van een sociaal-wetenschappelijk onderzoek naar 
standen van zaken wereldwijd, maar een gedeelde normatieve overtuiging van de opstellers van deze Verklaring - en dus een ideaal en geen feit, zoals de preambule ook uitdrukkelijk stelt. ${ }^{5} \mathrm{Bij}$ het ondertekenen ervan door overheden die deze rechten met voeten treden, spelen politieke motieven en economische belangen een grote rol. Deze constatering - het gaat hierbij niet om een universele, transculturele waarheid - betekent dat de waarde die met deze zinsnede wordt uitgedrukt, voortdurend bevestiging vanuit diverse culturen behoeft, wil ze geen dode letter worden. ${ }^{6}$

In de tweede plaats staat de erkenning van cultureel pluralisme haaks op wat bekend staat als 'de liberale moraal' - die niet verward mag worden met de opvattingen van politieke liberale partijen. De term slaat op de fundering van de morele grondslag van de (Westerse georiënteerde) grondwetten. De daarin verwoorde waarden komen zoals men het in Nederland vaak uitdrukt - voort uit de 'joodschristelijke' traditie in combinatie met Humanisme en Verlichting. Deze waarden hebben zich - is de gedachte - van hun afkomst losgemaakt en zijn gemeengoed geworden (Taylor 2002:89). Ik denk dat men hierbij wezenlijke punten over het hoofd ziet. Wat in de geschiedenis sociaal geconstrueerd is, kan in een latere ontwikkeling ongedaan worden gemaakt -ook als het een tijd lang voor algemeen beschaafd doorgaat, men denke aan de voorgeschiedenis van de Tweede Wereldoorlog. Deze visie lijkt mij een voorbeeld van een waarheidsaanspraak vanuit bepaalde tradities die zonder empirisch onderzoek wordt veralgemeniseerd tot een algemeen geloof. Om deze reden is de inductieve weg van de dialoog de enige methode om tot bredere overeenstemming te komen en gemeenschappelijke waarden van de wereldsamenleving langdurig te onderbouwen.

In dit proces neemt men de waarheidsaanspraken van religieuze tradities serieus. Religies dragen immers fundamentele inzichten in het bestaan over en daarmee inzicht in het leven en de waarden die mensen wel en niet moeten nastreven. Ik geef een

\section{5 http://www.unhchr.ch/udhr/lang/dut.htm}

6 Men zie voor visies op mensenrechten vanuit verschillende wereldreligies de bundel Human Rights and Religious Values, m.n. voor de spanning tussen de noodzaak van hun universele geldigheid ervan en de noodzaak van culturele en religieuze onderbouwing en formulering ervan in de bijdragen van drie juristen in deze bundel: An-Na'im, De Waardt en De Gaay Fortman (1995). Zie ook Tennekes-Griffioen (2002). 
voorbeeld dat aan de Abrahamitische religies is ontleend. Zij beschouwen mensen als door God geschapen en als zodanig gelijkwaardig. Van hieruit geloven zij dat mensen in beginsel met een zelfde moraliteit zijn uitgerust. 'In beginsel', want niemand zal beweren dat deze moraliteit van de mens overal en altijd goed vorm heeft gekregen in het leven. Als men het religieus pluralisme serieus neemt zal men moeten erkennen dat deze 'Abrahamitische' visie op mens en samenleving internationaal één van de vele visies is. Zowel seculiere als monotheïstische als non-theïstische religieuze visies zijn, politiek gezien, meningen van groepen mensen en hun voorstellen aan anderen. In de wisselwerking tussen religieus tradities met al hun innerlijke pluraliteit kunnen mensen elementen van andere tradities overnemen of verwerpen. Dat proces is de eeuwen door gaande en is door de globalisering en internet geïntensiveerd. De uitkomst moeten we afwachten. De rechten en plichten van mensen zijn neerslag van onderhandelingsprocessen tussen mensen met uiteenlopende levensovertuigingen en als zodanig historische constructen. De toepassingen ervan zijn contextueel. Daarom zijn ze beïnvloed door locale religio-culturele inzichten en sociaal-economische processen en machtsverhoudingen.

De relatie van politiek en levensbeschouwelijke organisaties is lastig. Ze kunnen niet zonder elkaar maar ook niet met elkaar. De politiek beslist over wetgeving en neemt besluiten op grond van inzicht in complexe problemen op grond van waarden die men in politieke stromingen erkent. Politici zijn dus zelf deel van tradities die waarden erkennen, propageren en toepassen in de vormgeving van de samenleving. Deze politieke tradities zijn verweven met levensbeschouwelijke tradities. De overheid van een land is voor haar waarden dus van levensbeschouwelijke tradities afhankelijk. De grondwaarden staan onophoudelijk ter discussie, niet alleen wat betreft hun toepassing en uitwerking maar daarmee ook wat betreft hun geldigheid en prioriteit. Omdat politieke stromingen zich groeperen naar gelang hun visies op waarden en de prioriteiten tussen deze waarden - bijvoorbeeld: eerst solidariteit of eerst persoonlijke vrijheid - zijn politieke stromingen en levensbeschouwelijke stromingen met elkaar verweven. De religieuze leider heeft opvattingen over praktische zaken seksualiteit, promiscuïteit, aids en voorbehoedsmiddelen en de omgang met buitenlanders - maar de minister beslist of het volk doet wat het wil. De minister heeft opvattingen over menselijke waarden, 
maar is wat waarde-tradities betreft meestal een leek met aanvechtbare opinies. De situatie is nog complexer, want het gezag van zowel de minister als de bisschop kan door leden van de politieke partij of religieuze gemeenschap ter discussie worden gesteld. Dit neemt niet weg dat de politiek waarden toepast bij de oplossing van complexe problemen en de brede reflectie op waarden-tradities aan anderen moet overlaten: aan levensbeschouwelijke organisaties met hun instituties voor reflectie en besluitvorming. Ernst-Wolfgang Böckenförde, rechter in het Duitse Bundesverfassungsgericht, heeft dit ooit op een klassiek geworden manier als volgt verwoord: de vrije geseculariseerde staat leeft uiteindelijk van vooronderstellingen die hij zelf niet kan garanderen (Böckenförde 1976:60). Dat wil zeggen dat de samenleving en de overheid voor deugden en waarden op levensbeschouwelijke instituties is aangewezen die zich in allerlei organisaties, zoals scholen, kerken, zendo's en beschouwelijke afdelingen van de media presenteren. De reflectie op levensbeschouwelijke waarden is de expertise van filosofie en theologie - vakgebieden die met elkaar verweven zijn omdat neutrale wijsbegeerte niet bestaat en theologie in vrijheid wordt beoefend, loyaal en kritisch ${ }^{7}$.

In een plurale cultuur is de overheid voor het 'waarden-debat' op de dialoog tussen mensen van verschillende overtuigingen aangewezen. De vraag is hoe dit 'gesprek' gestimuleerd kan worden zonder dat het een speelbal van politieke of commerciële krachten wordt. De geloofsdoordenking van de diverse tradities heeft hierin een cruciale taak. Maar juist ook de theologie is in een crisis geraakt.

\section{DE CRISIS VAN DE KLASSIEKE THEOLOGIE}

De klassieke theologie is in een crisis geraakt. Deze crisis heeft meer oorzaken die alle op de een of andere manier met de veranderingen in de cultuur van doen hebben: secularisatie in de zin van terugloop van het ledental van de kerken; verval van autoriteit; religieus pluralisme en individualisering; de gerichtheid van de theologie op de eigen traditie; een meer laïcistische opvatting van de scheiding tussen kerk en staat; en een wetenschapsopvatting waarin

7 Zie voor mijn visie op de relaties tussen 'religious studies', theologie, (godsdienst)wijsbegeerte en dialoog, mijn 2007. Zie voor de taak van de universiteit in verband met religieus pluralisme, Cheetham (2005). 
vooruitgang, consensus en neutraliteit voorop staan. Deze culturele veranderingen hebben de theologie in een crisis doen belanden. In deze paragraaf schets ik deze veranderingen en de gevolgen voor de christelijke theologie zoals die zich had ontwikkeld.

\subsection{Kerkelijke terugloop}

De terugloop van het ledental van de kerken, en met name van de staatskerken en publieke kerken uit de tijd vanaf de Reformatie heeft geleid tot een zeer sterke reductie van het aantal studenten in de theologie. Onder theologie versta ik hier de studie van de eigen traditie met oog op verantwoord geloof - in onderscheiding van de godsdienstwetenschap als de studie van aspecten van religie en vergelijking van aspecten van religies dwars door godsdiensten heen. De afname van het aantal studenten heeft tot verkleining van theologische faculteiten geleid, tot reductie van het aantal faculteiten en tot de omzetting van theologische faculteiten in departementen voor theologie en godsdienstwetenschap. Deze reductie heeft grote gevolgen voor de variëteit binnen theologische studies. Concentratie in enkele landelijke instellingen betekent dat de verschillende vleugels van de voormalige volkskerken niet meer in de staf van kleinere theologische faculteiten weerspiegeld worden.

\subsection{Verval van autoriteit}

Niet alleen de kerkleiding heeft een gezagsprobleem maar ook de theologie. Tot een halve eeuw geleden lazen de predikanten de boeken van 'hun' theologische staf, vooral van die in hun land. Tegenwoordig lezen de predikanten minder studieboeken - hun taken zijn ook veranderd; de boeken die zij lezen en de bijbelcommentaren die ze gebruiken kiezen zij op kwaliteit, bruikbaarheid en hun eigen belangstelling, en veel minder op denominatie. Een uitzondering zullen de evangelikale en orthodoxe vleugels zijn, maar juist die zullen tamelijk sterk internationaal georiënteerd zijn. Het aantal kerkleden dat theologische studieboeken leest, is sterk afgenomen. Dit betekent dat de staf van theologische faculteiten minder vanzelfsprekend achterland heeft en dat de meeste uitgevers kleinere oplagen maken en zorgvuldig moeten overwegen welke van de hun aangeboden boeken zij wel en welke zij niet publiceren. Tegelijk maakt de internationalisering van de wetenschap dat ook theologen meer en meer in gespecialiseerde internationale tijdschriften publiceren en zo minder zichtbaar zijn in hun cultuur, de publieke discussie en ook in hun eigen kerkelijke 
'achterland'. Dit leidt tot verder verlies van autoriteit van de theologie, niet alleen in eigen kring maar ook in de landelijke beeldvorming.

\subsection{Religieus pluralisme en individualisering}

Tegen het einde van de twintigste eeuw is het westerse gevoel van suprematie goeddeels weggevallen - zoals al eerder is aangeduid. Daardoor is het religieus pluralisme dat men zich altijd wel bewust was, van aard veranderd. Anders-geloven werd een optie. Sinds de theosofie zijn er altijd mensen geweest die vanuit 'het Oosten' zijn geïnspireerd, maar door de globalisering en met name films, nieuwsgaring en de toegankelijkheid van kennis via internet is religieus pluralisme van aard veranderd. Het is een realiteit van alledag geworden. Voor de één schept het onzekerheid, de ander biedt het een alternatief. De bricoleurs ondergaan invloeden vanuit meer tradities. Met het wegvallen van de onontkoombare religieuze autoriteiten staat ieder voor de taak zelf tot eigen overtuigingen te komen en de eigen 'levensbeschouwelijke identiteit' te 'construeren'. Hier spreken we niet over de variabele kwaliteit van het aanbod, maar over het wegvallen van de vanzelfsprekendheid van geloofsoverdracht en de grotere vrijheid van elke persoon - die voor de meeste mensen binnen hun sociale verbanden zal worden 'benut'. Voor de universitaire theologische faculteiten bracht dit een verschuiving in de studentenpopulatie met zich. Er kwamen meer zoekers en twijfelaars, ook onder de christelijke studenten. Daardoor is ook de opdracht van de theologische faculteiten qua vorming van studenten verschoven - en bleef vaak de praktijk achter bij de realiteit. George Newlands (2003) heeft beschreven hoe ingrijpend deze verschuiving voor de theologische faculteit in Glasgow is geweest. De Church of Scotland heeft in 2006 twee theologische seminaria vanuit de orthodox en evangelikale kring als opleidingsinstituut voor predikanten zijn erkend. Zij hebben meer studenten die predikant willen worden dan de vier Schotse theologische faculteiten ${ }^{8}$.

8 Voor de verschuivingen in de Schotse Reformed Church (Church of Scotland). Zie ook: Iain Torrance (2004); in de bundel Contextuality in Reformed Europe worden de veranderingen in de gereformeerd-hervormde kerken in de verschillende delen van Europa beschreven. 
Binnen de cultuur heerste langere tijd een ruimharige openheid voor ander geloof. Men sprak in termen van 'waar voor jou, waar voor mij' en gaf er de voorkeur aan over smaak en geloof niet te twisten. Na 2001, 9/11 ligt dit wat de Islam betreft anders, maar we moeten nog afwachten in hoeverre deze kritiek in de kritiek blijft steken dan wel in echte dialoog uitmondt.

\subsection{Theologische vernieuwing binnen de eigen traditie}

Binnen kerk en theologie heeft men deze ontwikkeling lang met argusogen bekeken, haar afgewezen maar niet kunnen tegenhouden. Alle goeds van de tweede helft van de twintigste eeuw aan oecumene, politieke betrokkenheid, aandacht voor geloofsleven en kerkopbouw, gedegen dogmatische studies en diepgaand en inspirerend bijbelonderzoek heeft niet kunnen verhinderen dat 'de theologie' met vrijwel lege handen staat tegenover de pluralisering. Klassieke dogmatische studies over problemen die mensen de eeuwen door hebben beziggehouden - voorzienigheid en vrije wil; drie-eenheid; twee naturen; de oorsprong van het kwaad; genade en verdienste - zijn voor de meeste mensen, ook veel predikanten en meelevende kerkleden, nauwelijks relevant. Mijns inzien ligt dat niet aan de onderwerpen, maar aan de manier waarop men ze meestal behandelt, vanuit de geschiedenis van de christelijke leer en niet vanuit het levensgevoel van mensen en de alternatieve levensbeschouwingen. De kerk in een land van zoekers heeft andere theologie nodig dan de 'established church', meer apologetisch en dialogisch. Om deze opvatting te ondersteunen geef ik een klein voorbeeld. De ontmoeting met moslims wijst men aan de islamoloog toe en niet aan de dogmaticus, de filosoof, de ethicus en de praktisch theoloog - alsof een dogmaticus zich aan een faculteit voor islamitische theologie in een islamitisch land prettig zou voelen bij een 'christendommoloog' in plaats van bij zijn collega kalam. De 'Auseinandersetzung' met alternatieve geloofswijzen is traditioneel uitbesteed aan godsdienstwetenschappers en maakt geen deel uit van de eigen geloofsdoordenking. Men scheidt tussen interne geloofsdoordenking en externe geloofsverantwoording, terwijl die twee voor de zoekers samengaan.

\subsection{Scheiding Kerk - Staat}

In een aantal westerse landen werken de secularisatie in de zin van ontkerkelijking, de re-religionisering en het religieus pluralisme een sterkere scheiding van kerk en staat in de hand. De staat moet zich 
verre houden van religie - in de vorige paragraaf hebben we uitvoerig bij de verhouding van de overheid en levensbeschouwelijke stromingen stil gestaan en verdedigd dat de overheid nooit levensbeschouwelijk neutraal kan zijn (maar groepen wel gelijk kan berechtigen). De tendens tot een striktere scheiding van kerk en staat verzwakt de positie van de theologie in het universitaire bestel. In de mate waarin een overheid of een departement voor hoger onderwijs en wetenschappelijk onderzoek zich wat betreft het publieke domein 'neutraal' - in de zin van nietreligieus bepaald en los van religieuze organisaties - opstelt, is de theologie die banden onderhoudt met religieuze groeperingen verdacht. Hoe omvattender iemands geloofsvoorstellingen, des te verdachter zijn wetenschappelijkheid. Dit beleid heeft ernstige consequenties voor de theologie. Aan staatsuniversiteiten in landen als de USA, Frankrijk (met uitzondering van de Elzas) en Nederland mag er geen theologische faculteit in strikte zin aan een staatsuniversiteit bestaan (Dyrness 2003). Daarom zijn de theologische faculteiten in de USA aan private universiteiten verbonden; daarnaast bestaan er talloze private seminaries die door kerkgenootschappen en particulieren worden gefinancierd. De combinatie van de scheiding van kerk en staat en de godsdienstvrijheid zijn er de oorzaak van dat godsdienstvrijheid tot een individuele, kritiekloze vrijheid kan worden.

\subsection{Wetenschapsopvatting: vooruitgang en consensus}

Ook waar er in West-Europa wel theologische instellingen bestaan aan staats- en private universiteiten is de 'secularisatie' van het wetenschapsbedrijf merkbaar. Veel collega's aan de universiteit vinden dat onderzoek neutraal moet zijn - ik ga hier voorbij aan de discussies in hoeverre neutraliteit mogelijk is. Dit leidt tot wat wel 'descriptivisme' is genoemd. Onderdelen van de theologie gelden als wetenschappelijk - zoals tekstkritiek, historische studies, beschrijvingen van het denken van grote theologen en denkers - en van andere wordt de wetenschappelijke kwaliteit als zwak beschouwd - zoals praktische theologie in relatie tot kerkelijk beleid, geestelijke vorming, stellingnemende dogmatiek, dialogische studies in relatie tot anders denkenden. De 'zwakke' theologische vakken delen dit lot met soortgelijke vakken in andere faculteiten zonder zwaar descriptief of analytisch gehalte, zoals theoretische pedagogiek, klinische psychologie, onderdelen van huisartsengeneeskunde en wijsbegeerte die zelf denkt. Terzijde, het 
is merkwaardig dat het na-denken van grote denkers die zelf nooit seculiere subsidies hadden verworven, wel als echte wetenschap geldt maar diens activiteit - zelf denken - in onze context niet: zelf denken over belangrijke vragen die men niet empirisch en descriptief kan beantwoorden.

In de discussies over de theologie als wetenschap nemen theologen soms hun toevlucht tot een wetenschapstheoretische discussie die moet aantonen dat geen enkele wetenschap geheel neutraal kan zijn. Vele malen kan men lezen dat men onder verwijzing naar klassieke studies in de wetenschapsleer als die van Michael Polanyi en Thomas Kuhn zegt dat elke discipline binnen een bepaald paradigma werkt, om daartoe te verantwoorden dat de christelijke theologie binnen een christelijk paradigma staat. Deze redenering gaat voorbij aan het seculiere punt in de verschuivingen binnen het wetenschapsbedrijf. Descriptief onderzoek is gericht op consensus en dus op herhaalbaarheid van waarnemingen en conclusies. Kenmerk van de waarheid is instemming van deskundigen. Veel onderzoek is bovendien gericht op vooruitgang qua kennis en techniek. Een voorbeeld is onderzoek naar een stof die een medicijn naar de zieke plaats in een bloedvat kan 'brengen'. Men weet welke stof genezend werkt maar nog niet hoe men het geneesmiddel ter plekke kan 'afleveren'. Een onderzoeksaanvrage kan zich dan richten op het 'gat' in de kennis - en men kan daarnaar zoeken in een internationaal onderzoekprogramma en de resultaten van diverse pogingen nauwkeurig in een specialistisch tijdschrift rapporteren. Veel onderzoek gaat om vooruitgang van beschrijvende kennis en consensus. Zulk onderzoek is levensbeschouwelijk neutraal.

Levensbeschouwelijk gericht onderzoek mist deze gerichtheid op feitenkennis want het is gericht op inzicht in het leven in de brede verbanden waarin het staat. Ik heb grote eerbied voor gedegen onderzoek naar de natuur, de historie, de uitleg van klassieke geschriften, naar wat mensen feitelijk geloven, denken en doen, enzovoorts, maar daarnaast ook voor onderzoekers die in staat zijn de culturele ontwikkelingen als geheel te duiden, te analyseren waar waarden van verschillende culturen met elkaar overeenstemmen, waar ze elkaar weerspreken en op welke punten ze wellicht van elkaar kunnen leren. Het lijkt mij voor de samenleving erg belangrijk dat moslims zelf hun traditie bestuderen en doordenken met oog op de vragen van de plurale globaliserende samenleving en boeddhisten 
nagaan op welke wijze westerse boeddhisten passende meditatievormen kunnen vinden en hoe zij zich tot de samenleving verhouden.

Dit soort academische theologie (inclusief de doordenking van boeddhisme en humanisme) voldoet niet aan de criteria van het heersende wetenschapsparadigma in de meeste westerse landen. Laat ik een voorbeeld geven. Theologische studies naar Augustinus' visies op de zonde, de aard van religieus gebruik van taal of heresie missen de urgentie van een medisch of biologisch onderzoek zoals zojuist beschreven. Het onderwerp is ietwat vaag; er is al veel over geschreven, en of het ergens toe leidt behalve tot een boek in gespecialiseerde bibliotheken is de vraag. Vanuit de gedachte dat wetenschappelijk onderzoek neutraal moet zijn, valt de onderzoeksvraag naar de aard van de zonde of de drie-eenheid buiten de wetenschap. Deze onderzoeksvragen zijn ten eerste niet neutraal te beantwoorden, ten tweede is hun onderwerp ongrijpbaar en daarom zal het, ten derde, nooit tot consensus leiden. 'In deze tak van wetenschap is het blijkbaar voldoende om deel te nemen aan de internationale discussie' - deze uitspraak van een adviseur over een aanvrage uit een Faculteit van Wijsbegeerte formuleert exact om welke bezwaren tegen normatief onderzoek het gaat.

Deze visie op de neutraliteit van wetenschap - vooruitgang en algemene instemming met controleerbare resultaten van onderzoek wreekt zich ook in de strategie van wetenschapsfinanciering waarin steeds meer geld via competitie moet worden verworven. In de Nederlandse situatie is het zo geregeld dat een commissie uit een lange lijst aanvragen een voorselectie maakt van aanvragen die mogen worden uitgewerkt en dan definitief ingediend. De uitgewerkte aanvragen worden elk aan vier experts toegezonden, waarvan enkele personen uit een enigszins verwante onderzoekstraditie en enkele anderen uit andere 'richtingen' of vakgebieden. Deze procedure heeft nadelen voor onderzoeksvoorstellen die een bepaalde visie op het leven en de samenleving veronderstellen. De kans is gering dat de vier adviseurs (referees) alle vier een zeer lovende bespreking van het voorstel geven. In normatieve vakken - waarin de levensbeschouwelijke waarheidsvraag aan de orde is - uiten mensen van andere richtingen voorbehouden of geven scherpe kritiek omdat zij niet instemmen met de aanpak en veronderstellingen waarop deze rust. Mensen uit descriptieve vakken vrezen dat het onderzoek niet tot consensus en 
dus niet tot vooruitgang zal leiden. De bestuurlijke implicatie van deze beoordelingsstrategie is dat dergelijke voorstellen eigenlijk nooit een zelfde lovende waardering krijgen als onderzoeksvoorstellen die van meer gangbare, 'neutraler' ideeën uitgaan. Voor de theologie speelt de secularisatie hierbij mee in zoverre veel onderzoekers in aanpalende disciplines van mening zijn dat levensbeschouwelijk gekleurd onderzoek geen middelen uit de staatskas mag ontvangen. Hier komt bij dat er sinds de opleving van de belangstelling voor religie, in allerlei universitaire faculteiten onderzoek naar psychologische, sociale en andere aspecten van religie wordt gedaan. De theologie heeft dus geen streepje voor wat betreft omvattende kennis van religie maar juist een nadeel.

Omdat externe financiering van onderzoek steeds belangrijker wordt, is er binnen de theologie een sterke tendens tot 'vergodsdienstwetenschappelijking'. Men ziet dat in de leus van veel bijbelwetenschappers die zeggen dat de bijbel op precies dezelfde wijze moet worden uitgelegd als alle andere geschreven teksten enerzijds is dit terecht, omdat men alle aspecten van de bijbel open en vrij kan en moet onderzoeken, anderzijds is het noodzakelijk dat men de bij het unieke voorwerp van onderzoek passende methoden kiest. Op overeenkomstige wijze zegt een godsdienstpsycholoog dat het onderzoek geen rekening houdt met het al dan niet bestaan van God, zegt menig godsdienstfilosoof dat hij religie vanuit een buitenperspectief doordenkt zonder de godsidee aan te hangen of te verwerpen en onderzoekt een historicus het historisch verloop van het christendom en niet de kerkgeschiedenis. Veel christelijke theologie is in feite godsdienstwetenschappelijke studie van aspecten van het christendom. Het onderscheid tussen islamologie en islamitische theologie ontgaat velen.

Zo zien we dat de theologie door een reeks van factoren in een stevige crisis verkeert: secularisatie, individualisering, verval van autoriteiten, terugloop van het aantal predikantsplaatsen, religieus pluralisme, een striktere opvatting van de scheiding van kerk en staat, en wetenschapsbeleid waarin neutraliteit, consensus en vooruitgang voorop staan.

\section{VAN CONFESSIONELE NAAR INTERRELIGIEUZE FACULTEIT}

Een verdere vergodsdienstwetenschappelijking van de theologie zou onvermijdelijk leiden tot een uiteenvallen van de theologie in 
literaire en sociaal-wetenschappelijke onderzoeksvelden. De theologische opleidingen zullen onderwijsinstituten worden die voor de verschillende aspecten van de theologie docenten uit diverse wetenschapsgebieden zullen aanstellen. De eenheid van de theologie gaat op die manier verloren. De eenheid van de theologie is in de loop van de tijd op allerlei manieren uitgedrukt, zoals bezinning op het Woord van God, studie van het geloof in de God van de bijbel of studie van de geopenbaarde kennis van God. Hoe men het ook omschrijft, steeds gaat het om een studie die zowel de Schriften als de context als de tussenliggende historie omvat. De theologie vergt dat onderzoekers en onderwijzers van elkaars werk op de hoogte zijn en allen dat doel dienen: verantwoord christelijk geloof. Elke theologische discipline heeft descriptieve en normatieve elementen. De theoloog-sociaal wetenschapper zal niet alleen beschrijven wat er in het land gaande is, maar ook bedenken welke implicaties dit voor de kerk heeft. De exegeet is niet klaar met een beschrijving van de teksten als teksten uit het verleden - zoals een Egyptoloog zich niet behoeft af te vragen welke betekenis zijn hiëroglyfen voor de mensen nu hebben - maar is medeverantwoordelijk voor de vertaling en vertolking van hun zeggingskracht in het heden - zo men wil: de rol die de Bijbel of de Koran, de Vedische geschriften en de Bhagavadgita, de Gesprekken van de Boeddha, enzovoorts kunnen hebben in de identiteitsconstructie van religieuze en niet-religieuze personen en gemeenschappen. Naast de vraag hoe mensen de Koran of de Bijbel gebruiken in hun identiteitsconstructie staat de vraag of de teksten daarin willekeurig of met goede redenen worden gebruikt. Deze vragen reiken verder dan alleen een wetenschappelijke reconstructie van de betekenis van de tekst in de context van het verleden.

Dit betekent dat de theologie niet moet verdwijnen als een zelfstandige wetenschap. Juist in een plurale cultuur met vrijheid van meningsuiting zijn er kritische instanties nodig die beweringen tegen het licht houden. In een tijd van verval van een gemeenschappelijk zinkader, is het nodig dat de bronnen van inzicht in het leven en moraliteit binnen de universiteit worden bestudeerd in eigen rechte en in hun betekenis voor het heden.

Voor de inrichting van de confessionele theologie (theology proper) bestaan er internationaal drie modellen (vgl mijn 1998:1) theologische seminaria, al dan niet gefinancierd door de kerk, de overheid of een groep particuliere burgers; 2) Theologische 
Faculteiten of afdelingen theologie in Faculteiten van Geesteswetenschappen - in sommige landen alleen aan private universiteiten en in andere landen ook aan staatsuniversiteiten; 3) een aanvullingsmodel: godsdienstwetenschappelijke studie aan universiteiten (exegese, geschiedenis van het christendom, sociale wetenschappen \& religie, enzovoorts) met een kerkelijke aanvulling (voor confessionele vakken als dogmatiek en kerkrecht, en praktische theologie). Ook dit aanvullingsmodel komt op allerlei manieren voor, afhankelijk van de vormgeving van de scheiding tussen kerk en staat en andere historische of praktische factoren. De eerste twee modellen staan in de Nederlandse organisatie van theologie bekend als simplex ordo en het derde als duplex ordo. Simplex ordo staat voor integrale christelijke theologie en duplex ordo voor godsdienstwetenschap met een theologische vervolgstudie.

Leden van andere religieuze gemeenschappen dan christelijke hebben ook opleidingen gesticht - joodse bijvoorbeeld in Londen, Amsterdam en Berlijn - of zijn doende ze op te richten. In islamitische landen en in de hindoe cultuur is men gewend aan de parallel van de simplex ordo: men wordt ingevoerd in de eigen traditie en leert ook wat men als imam of pandit moet weten en kunnen. In landen waar de overheid christelijke opleidingen subsidieert, ligt voor de hand dat ook islamitische en hindoeïstische instellingen zullen worden gesubsidieerd. West-Europese overheden zullen hierbij aarzelen als het om losstaande nieuwe opleidingen gaat. De aarzelingen komen voort uit zorg over een haperend proces van integratie; separate instellingen buiten het bestaande universitaire systeem lopen gevaar het integratieproces te vertragen. Ook zal het langer duren voor zulke opleidingen aan westerse academische standaards voldoen. In Nederland zijn er op initiatief van moslims twee eigenstandige theologische instellingen opgericht. Beide hebben slechts een kleine instroom van studenten met de kwalificaties die voor toelating tot de universiteit zijn vereist. Bovendien hebben vertegenwoordigers van de islamitische gemeenschap liever dat de opleiding van imams de studenten in nauwer contact brengt met anders-denkende studenten en aan een voluit academische instelling is gevestigd. Dit impliceert dat de islamitische gemeenschap zou kunnen opteren voor het tweede of het derde model, vestiging van een integrale theologische opleiding 
bij een theologische faculteit of een (duplex ordo) theologische aanvulling na een studie islamologie.

De overwegingen in de voorgaande paragrafen over de problematiek van multiculturaliteit en religieus pluralisme en over de crisis in the klassieke christelijke theologie leiden mij tot een voorkeur voor vestiging van meer religieuze en levensbeschouwelijke 'theologische' opleidingen aan één Faculteit. Deze oplossing heeft voor de opleiding de volgende voordelen: 1) de studenten worden integraal opgeleid in hun eigen traditie en leren die traditie te verantwoorden ten overstaan van de bronnen van de traditie, de geschiedenis van de traditie, de vragen van de huidige geloofsgemeenschap en ten overstaan van andersdenkenden; 2) de studenten leren zowel teksten uitleggen als teksten uit een andere tijd, als ze te vertolken en toe te passen in de eigen context; ze leren de competentie om te beschrijven en om zelfstandig een mening te vormen; 3) in de gezamenlijke colleges leren de studenten respect voor anders denkenden, leren hun visie op het leven beter kennen en kritische vragen van anderen te beantwoorden; 4) de docenten staan aan dezelfde uitdagingen bloot als de studenten; 5) een dergelijke Faculteit krijgt expertise in diverse klassieke talen, Hebreeuws, Grieks, Sanskriet en Arabisch, in de geschiedenis van verschillende religies en culturen, in het denken en de spiritualiteit van verschillende tradities en bouwt zo een unieke expertise op wat religie betreft; 6) de kritische vragen van anderen houden studenten en docenten wakker en geven hun weinig gelegenheid om zich met haarkloverijen bezig te houden en dwingen hen om de relevantie van het onderwerp van hun studies aan te geven.

Een dergelijk samenstel van opleidingen de broodnodige uitwisseling van gedachten over maatschappelijke onderwerpen in het publieke domein ondersteunen, zowel door studie als door thematische bijeenkomsten. Aan het slot van paragraaf 2 hebben we al gesteld dat de overheid in de samenleving waarden moet vooronderstellen die zij niet zelf genereert. Aan de andere kant moet de overheid verschillende levensbeschouwelijke tradities gelijk berechtigen. Omdat de overheid neutraal moet zijn, is haar probleem welke waarden zij moet stimuleren en zelfs als zij de waarden die in de grondwet zijn verankerd wil verbreiden, is ze van anderen afhankelijk want politici en ambtenaren zijn zelf als zodanig geen opvoeders, rechters, docenten of filmmakers. Bovendien verschuift de inhoud van de waarden die in de grondwet zijn verankerd 
historisch en contextueel. De nationale gemeenschap heeft dus zelf belang bij een dialoog tussen levensbeschouwelijke richtingen over de waarden die de gemeenschap kunnen samenbinden en dragen. Maar zonder institutionalisering kan het woord 'dialoog' gemakkelijk een modewoord worden, een panacee om de tegengestelde opvattingen in de samenleving te verzoenen. Mij lijkt dat een dergelijk samenstel van 'theologische' opleidingen kan helpen om de relativistische sfeer van 'ik maak zelf wel uit wat ik geloof, en zal jou niet lastig vallen' te boven te komen. Een dergelijke faculteit kan een kweekvijver van levensbeschouwelijke dialoog en publieke discussie worden - juist doordat men de eigen traditie bestudeert, doordenkt en verantwoordt.

Tot slot, aan de Vrije Universiteit hebben we een begin gemaakt met een dergelijke Faculteit. Sinds 2005 is er een BAopleiding islamitische theologie en een MA-opleiding voor islamitische geestelijk verzorgers in zorginstellingen en gevangenissen. Per september 2008 worden er varianten voor MAislamitische jeugdzorg en islamitische levensbeschouwelijke vorming opengesteld. Er wordt accreditatie gevraagd voor een driejarige MA Islamitische Theologie en een onderzoek-master van twee studiejaren. De BA-studenten hebben een aantal vakken samen; daarbij wordt onder meer van hen gevergd dat ze een stelling van een ander kritiseren en later een inzicht van een ander vanuit diens gezichtpunt verdedigen - in gemengde kleine groepjes. De moslim docenten menen dat als hun studenten hier niet tegen opgewassen zijn, zij als imam geen goede voorganger voor hun jongeren kunnen zijn. De decaan in 2005-8, Bram van de Beek, verwoorde dit eens zo: als onze christelijke studenten de drie-eenheid niet aan een moslim kunnen uitleggen, kunnen ze dat ook niet aan hun catechisanten. In een dergelijk facultair verband is er alle ruimte om verschillen te benoemen en te bespreken - daarnaast zoekt men ook naar overeenkomsten. Vanuit integratiebeleid én vanuit de tradities zelf gezien lijkt me een dergelijk samenstel van opleidingen en studies een waardevolle ontwikkeling.

\section{Literatuurverwysings}

Almond, G A R, Appleby, S \& Sivan E 2003 (eds.). Strong Religion. The Rise of Fundamentalisms around the World. Chicago: The University of Chicago Press.

An-Na'im, A et al. (eds.) 1995. Human Rights and Religious Values: An Uneasy Relationship? Amsterdam / Grand Rapids: Rodopi / Eerdmans. 
An-Na'im, Abdullahi 1995. Toward an Islamic Hermenutics for Human Rights, in An-Na'im, A et al. (eds.), Human Rights and Religious Values: An Uneasy Relationship? Amsterdam / Grand Rapids: Rodopi / Eerdmans, 229-242.

Berger, P 1999. The Desecularization of the World: A Global Overview, in Berger P L (ed.), The Desecularization of the World. Resurgent Religion and World Politics. Grand Rapids: Eerdmans, 1-18

Böckenförde, Ernst-Wolfgang 1976. Staat, Gesellschaft, Freiheit. Frankfurt.

Brinkman, M E, Schreurs, N F M, Vroom, H M \& Wethmar, C J (eds.) 2003. Theology between Church, University, and Society. Assen: Van Gorcum.

Cheetham, D 2005. The University and Interfaith Education. Studies in Interreligious Dialogue 15(1), 16-35.

Davie, G 2002. Europe: The Exceptional Case. Parameters of Faith in the Modern World. London: Darton, Longman and Todd.

De Gaay Fortman, B 1995. Human Rights, Entitlement Systems and the Problem of Good Governance, in An-Na'im, A et al. (eds.), Human Rights and Religious Values: An Uneasy Relationship? Amsterdam / Grand Rapids: Rodopi / Eerdmans, 62-77.

De Waart, P J I M 1995. International order and Human Rights: A matter of Good Governance, in in An-Na'im, A et al. (eds.), Human Rights and Religious Values: An Uneasy Relationship? Amsterdam / Grand Rapids: Rodopi / Eerdmans, 45-61.

Dyrness, W 2003. The Church, the University and Culture: Can Theology Find its Way? An American Perspective, in Brinkman, M E, Schreurs, N F M, Vroom, H M \& Wethmar, C J (eds.), Theology between Church, University, and Society. Assen: Van Gorcum, 47-60.

Gort, J, Jansen, H \& Vroom H M 2006. Religions View Religions. Explorations in Pursuit of Understanding. Amsterdam / New York: Rodopi.

Newlands, G 2003. Theology and Cultural Change: A Variety of Students, in Brinkman, M E, Schreurs, N F M, Vroom, H M \& Wethmar, C J (eds.), Theology between Church, University, and Society. Assen: Van Gorcum, 164-174.

Okumus, F 2008. De Profeet als voorbeeld, in El-Bouayadi-van de Wetering, S \& Vroom H (eds), In het spoor van Jezus en Mohammed. Op zoek naar God en hoe te leven. Zoetermeer / Kapellen: Meinema / Pelckmans, 109-124.

Scheffer, P 2007. Het land van aankomst. Amsterdam: De Bezige Bij.

Smith, W C 1964. The meaning and end $f$ religion. New York: The New American Library of World Literature.

Taylor, C (2002). Varieties of Religion Today. William James Revisited. Cambridge (Mass.): Harvard University Press.

Tennekes, J \& Griffioen, S 2002. Culturele universalia en multicultureel samenleven, in Lucassen J \& De Ruijter, A (eds.), Nederland multicultureel en pluriform? Een aantal conceptuele studies. Aksant: Amsterdam, 85-140. 
Torrance, I 2004. From Established Church to Minority Church: A Scottish History, in Lienemann-Perrin, C, Vroom, H M \& Weinrich, M (eds.), Contextuality in Reformed Europe. The Mission of the Church in the Transformation of European Culture. Amsterdam / New York: Rodopi, 179194.

Vroom, H M 1997. Staatsvakken en kerkelijke vakken aan openbare universiteiten. Skrif en Kerk 18(1), 210-231

-, 1998. De inrichting van de theologie in de plurale cultuur. Skrif en Kerk 19(2), 419-437

-, 2003. Theology and Religious Studies: 'Progress and Relevance', in Brinkman, M E, Schreurs, N F M, Vroom, H M \& Wethmar, C J (eds.), Theology between Church, University, and Society. Assen: Van Gorcum, 88105.

-, 2007. Philosophy of Religion in a Pluralistic Culture, in Sanders A F (ed.), D.Z. Phillips' Contemplative Philosophy of Religion. Questions and Responses, Aldershot, Hampshire: Ashgate, 181-196.

Wethmar, C J 1997. Ecclesiology and theological education: A South African reformed perspective. Skrif en Kerk 18 (2), 415-430.

-, 2003a. Theological Education in an Ecumenical Context: Principles and Procedures of the Pretoria Mehod, in Brinkman, M E, Schreurs, N F M, Vroom, H M \& Wethmar, C J (eds.), Theology between Church, University, and Society. Assen: Van Gorcum, 61-74

-, 2003b. Theology Between Church, University and Society, in Brinkman, M E, Schreurs, N F M, Vroom, H M \& Wethmar, C J (eds.), Theology between Church, University, and Society. Assen: Van Gorcum, 217-238. 